\title{
ASSESSMENT OF THE FREQUENCY OF INTAKE OF SELECTED SOURCES OF DIETARY FIBRE AMONG PERSONS COMPETING IN MARATHONS
}

\author{
Monika Bronkowska ${ }^{1}$,Aureliusz Kosendiak², Dagmara Orzet ${ }^{1}$ \\ ${ }^{1}$ Wrocław University of Life Sciences, Faculty of Biotechnology and Food Sciences, \\ Department of Human Nutrition, Józefa Chełmońskiego str. 37/41, 51-630, Wroclaw, Poland \\ ${ }^{2}$ Wrocław Medical University, Study of Physical Education and Sport, Wrocław, Poland
}

\begin{abstract}
Background. The knowledge about nutrition of the marathoners is insufficient. An insightful and personalized approach to the diet of long-distance athletes, including the consumption of important nutrients such as dietary fiber, is needed to improve the efficiency of their performance.

Objective. Estimation of the frequency of consumption of food products as a source of dietary fiber by people preparing for the marathon.

Material and Methods. The frequency of intake of selected dietary fiber sources by women $(\mathrm{n}=105)$ and men $(\mathrm{n}=87)$ aged 19 to 73 years, who compete in marathons. The Block questionnaire was used to assess the intake of fiber sources (whole grain cereals, vegetables, fruits, potatoes and legumes). Fiber consumption was expressed on a dot scale.

Results. Adequate dietary fiber intake was found in $44 \%$ of the marathon runners, but insufficient one - in $50 \%$ of the respondents. Diets of about $6 \%$ of the subjects were poor in dietary fiber. Lower dietary fiber intake was demonstrated in both men and women in the pre-marathon period, and was due to the recommended dietary fiber intake during this period. Conclusion. The study showed an insufficient intake of dietary fiber in all-day rations of most of the surveyed marathon runners. A statistically significantly lower dietary intake of marathoners (both women and men) was demonstrated before the marathon compared to the post-long distance period.
\end{abstract}

Key words: marathon runners, dietary behaviors, dietary fiber

\section{STRESZCZENIE}

Wprowadzenie. Wiedza na temat żywienia maratończyków jest ciągle niewystarczająca. Konieczne wydaje się wnikliwe i bardziej zindywidualizowane podejście do sposobu żywienia osób uprawiających biegi długodystansowe, w tym spożywania ważnych składników pokarmowych np. błonnika pokarmowego dla poprawy optymalizacji ich wydolności.

Cel. Ocena częstotliwości spożycia produktów stanowiących źródło błonnika pokarmowego przez osoby przygotowujące się do maratonu.

Material i metody. Analizowano częstotliwość spożycia wybranych źródeł błonnika pokarmowego przez kobiety (n=105) i mężczyzn (n=87) w wieku od 19 do 73 lat, którzy biorą udział w maratonach. Użyto kwestionariusza Block’a do oceny spożycia źródeł błonnika (produktów zbożowych z pełnego przemiału, warzyw, owoców, ziemniaków i nasion roślin strączkowych). Spożycie błonnika wyrażono w skali punktowej.

Wyniki. Wystarczające spożycie błonnika stwierdzono u 44\% badanych maratończyków, natomiast niewystarczające u 50\% respondentów. Diety około $6 \%$ badanych osób były ubogie w błonnik pokarmowy. Niższe spożycie błonnika pokarmowego wykazano zarówno u kobiet, jak i u mężczyzn w okresie przed maratonem i wynikało z zalecanego w tym okresie ograniczenia błonnika na rzecz węglowodanów przyswajalnych.

Wnioski. U większości badanych maratończyków stwierdzono niewystarczające spożycie błonnika pokarmowego w całodziennej racji pokarmowej. Wykazano statystycznie istotnie niższe spożycie błonnika pokarmowego u maratończyków (zarówno kobiet, jak i mężczyzn) przed maratonem w porównaniu do okresu po biegu długodystansowym.

Słowa kluczowe: maratończycy, zachowania żywieniowe, błonnik pokarmowy

Corresponding author: Dagmara Orzeł, Wrocław University of Life Sciences, Faculty of Biotechnology and Food Sciences, Department of Human Nutrition, Jozefa Chełmońskiego str. 37/41, 51-630 Wroclaw, Poland, e-mail: dagmara.orzel@upwr.edu.pl 


\section{INTRODUCTION}

Long-distance runs are becoming increasingly popular even among recreational runners. Fast exhaustion and loss of the ability of maintaining high intensity of physical effort result from almost complete depletion of glycogen reserves in muscles and liver. The knowledge about runners nutrition is, however, still insufficient. Nutritional mistakes are still being made in practice. An insightful and personalized approach to the diet of long-distance athletes, including the consumption of important nutrients such as dietary fiber, is needed to improve the efficiency of their performance [9].

Dietary fiber represents a complex of polysaccharide fractions that may be divided into: insoluble in water (e.g. lignins, cellulose and some hemicelluloses) and soluble fractions (pectin compounds, most of the hemicelluloses, some storage polysaccharides like guar gum, and $\beta$-glucans). It is constituted by chemically heterogeneous components originating from plants consumed by man, but also by carbohydrates that escape digestion and absorption in the small intestine but, in turn, are completely or partially fermented in the colon. Individual fractions differ between each other with their structure, physical properties and respective effects exerted in the gastrointestinal tract of man $[1,13]$.

In addition, dietary fiber is an important nutrient having a multi-oriented and beneficial effect upon human health. A high-fiber diet has been shown to significantly minimize the risk of development of diet-related diseases like: cardiovascular diseases, obesity, type 2 diabetes, and neoplasms [7, 16, 17]. Due to its water-binding and gel-forming capabilities and to its sorptive properties, dietary fiber serves many important physiological functions. It improves enteric peristalsis, reduces the risk of development of colon diverticula, hemorrhoids, and colorectal cancers [10]. It also plays a significant role in obesity prevention as its swelling causes slower emptying of the stomach and prolonged sensation of satiety. By binding salts of bile acids, dietary fiber affects lipid absorption and cholesterol metabolism. Both soluble dietary fiber in the form of $\beta$-glucan and pectins, as well as insoluble dietary fiber and lignins enhance excretion of sterols from the body [1, 13]. This substantiates the interest in natural sources of dietary fiber including e.g. cereal products, vegetables, and fruits [15].

The study aimed to determine the frequency of consumption of selected foods as a source of dietary fiber by people preparing for the marathon.

\section{MATERIAL AND METHODS}

The study covered 192 persons preparing for the marathon to be held in Wrocław. The surveyed runners were asked to complete a questionnaire regarding the frequency of intake of food products being the main sources of dietary fiber in their diet. The survey was conducted since May till August 2013. Women represented $54.7 \%$ and men $45.3 \%$ of the group. The mean age of women was 32.7 years (range: 20-57 years), whereas that of men was 35.1 years (range: 19-73 years). The mean body mass of women before the marathon accounted for $62.4 \mathrm{~kg}$ (range: $50-95 \mathrm{~kg}$ ), whereas after the marathon - for $60 \mathrm{~kg}$ (range: $48-86$ $\mathrm{kg}$ ). In the case of men, the respective values were as follows: $81.7 \mathrm{~kg}$ (range $63-112.7 \mathrm{~kg}$ ) and $78.6 \mathrm{~kg}$ (range 55-92.6 kg).

The frequency of intake of selected sources of dietary fiber were determined using a Block's questionnaire developed for the needs of the NHANES II survey and used in many countries [2, 15]. The questionnaire allowed collecting data about the usual frequency of consumption of wholemeal bread and other cereal products (e.g. flakes, coarse-grain groats), fruits, vegetables, potatoes, and legume seeds. The frequency of intake of these products was evaluated using a 5-point descriptive scale with numerical values assigned:

- less frequently than once a week - 0 pts.,

- about once a week - 1 pt.,

- 2-3 times a week - 2 pts.,

- 4-6 times a week -3 pts.,

- every day -4 pts. [2].

The frequency of intake of selected food products being sources of dietary fiber was expressed in a point scale (0-36 pts.). Three groups of respondents were distinguished based on the sum of points achieved:

- persons with sufficient intake of dietary fiber (>30 pts),

- persons with insufficient intake of dietary fiber (20-29 pts),

- persons whose diet is poor in dietary fiber $(<20 \mathrm{pts})$.

The statistical analysis of results was conducted using Statistica 10.0. package. Mean values of traits assigned to categories of the frequency of intake were compared with Kruskal-Wallis test. Letters a $\mathrm{b}$ in tables denote significant differences between mean values in rows at $p \leq 0.05$, whereas $n s-$ denotes insignificant differences.

\section{RESULTS AND DISCUSSION}

The analysis of the frequency of intake of selected sources of dietary fiber in everyday food 
Table 1. Frequency of intake of food products - being main sources of dietary fiber - by the surveyed athletes ( $\mathrm{n}=192)$

\begin{tabular}{|c|c|c|c|c|c|c|}
\hline \multirow{2}{*}{$\begin{array}{l}\text { Frequency of intake of food } \\
\text { products - sources of dietary } \\
\text { fiber }\end{array}$} & \multicolumn{3}{|c|}{ Women $(n=105)$} & \multicolumn{3}{|c|}{ Men $(n=87)$} \\
\hline & $\begin{array}{c}\text { before } \\
\text { marathon }\end{array}$ & $\begin{array}{c}\text { after } \\
\text { marathon }\end{array}$ & $\mathrm{p} \leq 0.05$ & $\begin{array}{c}\text { before } \\
\text { marathon }\end{array}$ & $\begin{array}{c}\text { after } \\
\text { marathon }\end{array}$ & $\mathrm{p} \leq 0.05$ \\
\hline less than once a week & 14 & 4 & $a-b$ & 8 & 7 & ns \\
\hline about once a week & 35 & 26 & $a-b$ & 23 & 14 & $a-b$ \\
\hline 2-3 times a week & 32 & 32 & ns & 35 & 24 & $a-b$ \\
\hline 4-6 times a week & 19 & 26 & $a-b$ & 15 & 25 & $a-b$ \\
\hline every day & 5 & 17 & $a-b$ & 6 & 17 & $a-b$ \\
\hline
\end{tabular}

a-b statistically significant differences at $\mathrm{p} \leq 0.05$

ns - statistically insignificant differences

Table 2. Assessment of dietary fiber intake in the surveyed groups of athletes $(n=192)$

\begin{tabular}{|c|c|c|c|c|c|c|}
\hline \multirow{2}{*}{ Dietary fiber intake } & \multicolumn{3}{|c|}{$\begin{array}{c}\text { Women }(\mathrm{n}=105) \\
\%\end{array}$} & \multicolumn{3}{|c|}{$\begin{array}{c}\text { Men }(n=87) \\
\%\end{array}$} \\
\hline & $\begin{array}{c}\text { before } \\
\text { marathon }\end{array}$ & after marathon & $\mathrm{p} \leq 0.05$ & before marathon & $\begin{array}{c}\text { after } \\
\text { marathon }\end{array}$ & $\mathrm{p} \leq 0.05$ \\
\hline sufficient & 22.9 & 41.0 & $a-b$ & 24.1 & 48.3 & $a-b$ \\
\hline insufficient & 63.8 & 55.2 & $a-b$ & 66.7 & 43.7 & $a-b$ \\
\hline poor & 13.3 & 3.8 & $a-b$ & 9.2 & 8.0 & $a-b$ \\
\hline
\end{tabular}

a-b statistically significant differences at $\mathrm{p} \leq 0.05$

ns- statistically insignificant differences

rations of the surveyed women and men showed no significant differences between groups of respondents with various BMI values. Table 1 summarizes the frequency of intake of food products - main sources of dietary fiber - by the surveyed athletes: women $(\mathrm{n}=105)$ and men $(\mathrm{n}=87)$. A statistically significantly lower frequency of intake of dietary fiber sources (cereal products, vegetables, potatoes, legume seeds, and fruits) was found in both women and men before the long-distance run compared to post-marathon period. Ca. $50 \%$ of women and $36 \%$ of men declared their consumption once a week or more seldom before the marathon, whereas after the marathon such a low frequency of dietary fiber intake was demonstrated in $28 \%$ of women and $24 \%$ of men. Ca. $18 \%$ of women and $24 \%$ of men declared the frequency of intake of dietary fiber-rich product to increase to more than 4 times a week after the marathon.

During the marathon, muscle glycogen and appropriate glucose concentration in blood serum are the key substrates for the working muscles. High reserves of glycogen in muscles and liver are indispensable for the apt metabolism during functional exercise. Fatigue during long-lasting physical efforts often results from muscle glycogen depletion and decreased serum level of glucose. It is, therefore, important to ensure the optimal reserves of glycogen both before and during the exercise. The development of an effective method of glycogen reserves accumulation is of key significance in the nutrition of persons practicing endurance sports. To increase glycogen reserves in muscles, carbohydrate supercompensation is applied 7-10 days before the competition, which enhances the accumulation of muscle and liver glycogen. Before the marathon, a runner needs to provide 400 to 600 $\mathrm{mL}$ of fluids and carbohydrates (1-4 g/kg body mass) to maintain appropriate levels of body hydration and blood glucose. While training for long-distance runs, a high-carbohydrate diet providing $60-70 \%$ of energy and appropriate intake of basic nutrients is recommended to ensure the optimal course of the training process. Further guidelines include minimal intakes of fat, protein, and dietary fiber $[6,18]$. In our study, the above recommendations explain the lower frequency of intake of food products being the main sources of dietary fiber by persons in the period of intensive training effort and during marathon in favor of an increased intake of easily available carbohydrates.

Table 2 presents results of the assessment of dietary fiber intake in the surveyed groups of athletes. Before the marathon, its intake was poor and insufficient in $77.1 \%$ of the women and $75.9 \%$ of the men. In this period, their diets were predominated by simple carbohydrates. In the post-marathon period, sufficient intake of dietary fiber was noted in ca. $45 \%$ of the surveyed athletes, whereas during intensive training before the long-distance run the sufficient intake of dietary fiber was demonstrated in only $23 \%$ of the runners.

Improper intake of cereal products, vegetables and fruits by athletes was demonstrated in studies conducted by other authors. A survey carried out among 
100 athletes, including 50 professional sportsmen (associated and representing sports clubs located in the Kujawsko-Pomorskie Province) and 50 amateur athletes, demonstrated that everyday intake of cereal products was declared by $45 \%$ of professionals and $39 \%$ of amateurs. $25 \%$ of the professional athletes and $17 \%$ of the amateurs declared no consumption of cereal products. Consumption of vegetables few times a day was declared by $48 \%$ of the professionals and $41 \%$ of the amateurs, whereas the same frequency of fruit intake was declared by $68 \%$ of the professional athletes and by $72 \%$ of the amateurs. Improper practices were also demonstrated in the consumption of meals before and after trainings [8].

Guidelines of rational nutrition for professional athletes and physically-active persons recommend the consumption of cereal products 4 times a day, including 3 main meals and one meal after physical exercises lasting min. one hour. Vegetables should be provided in every meal, whereas fruits should be consumed 2-3 times a day as they provide dietary fiber, vitamins, and minerals. In the study conducted by OstachowskaGasior [12], the knowledge of the above guidelines was confirmed in $30.6 \%$ of the 105 persons attending fitness clubs every day. In turn, a survey carried out by Szczepańska and Spałowska [14] among professional volleyball and basketball players demonstrated appropriate intake of cereal products in only $35 \%$ of the respondents which is indicative of poor nutritional knowledge of this group of athletes. Similar results were reported by Nowacka et al. [11], who showed everyday consumption of cereal products in barely $36.8 \%$ of the surveyed athletes practicing shooting sport and canoe slalom.

Endurance sports have become highly popular even among recreational runners. An increasing number of persons compete in marathons, half-marathons, and other forms of long-lasting physical activity. Runs, especially the long-distance ones, are perceived as a measure of physiological capabilities of an athlete body. Ample studies have demonstrated a positive effect of nutrition on athlete performance $[3,4]$.

Nutritional pattern and diet-related nutritional status may significantly affect the physical performance in endurance disciplines. An important element in nutrition of athletes and persons undertaking regular physical activity is the amount and type of ingested carbohydrates. Currently, the recommended amount of carbohydrates supplied with diet of long-distance runners should range from 6 to do $10 \mathrm{~g} / \mathrm{kg}$ body mass/ day and in the pre-competition period should provide $60-70 \%$ of energy. This allows increasing physical performance by $2-3 \%$. Following dietary guidelines, a diet of persons competing in running disciplines should provide $10-15 \%$ of energy from protein and $20-25 \%$ of energy from fats [4].
Durkalec-Michalski [5] evaluated the effect of diet balancing acc. to the above guidelines on body composition and performance capability of a selected group of persons competing in running disciplines. The balancing and rationalization of the nutritional pattern during intensive trainings (including increasing dietary fiber content in diet to $50 \mathrm{~g}$ /day) had a positive effect on: reduced content of fatty tissue, increased aerobic adaptation, and physical performance of the surveyed runners.

Abnormalities observed in the frequency of intake of important groups of food products (cereal products, vegetables, and fruits) among athletes competing in running disciplines point to the necessity of nutritional education of this population.

\section{CONCLUSIONS}

1. Sufficient intake of dietary fiber was demonstrated in $44 \%$ of the surveyed marathon runners. Everyday food rations of $50 \%$ of the analyzed athletes provided insufficient amount of dietary fiber, whereas these of ca. $6 \%$ of the athletes were poor in this dietary constituent.

2. No correlation was found between BMI value and frequency of food products consumption being sources of dietary fiber.

3. A statistically significantly lower intake of dietary fiber was demonstrated in long-distance runners (both women and men) before the marathon compared to the post-marathon period.

\section{Conflict of interest}

The authors declare no conflict of interest.

\section{REFERENCES}

1. Bienkiewicz M., Bator E., Bronkowska M.: Błonnik pokarmowy i jego znaczenie w profilaktyce zdrowotnej [Dietary fiber and its importance in health promotion] Probl Hig Epidemiol 2015;96(1):57-63 (in Polish).

2. Block $G$.: A review of validations of dietary assessment methods. Am. J. Epidemiol. 1982;115:492-505.

3. Currell K., Jeukendrup A.: Superior endurance performance with ingestion of multiple transportable carbohydrates. Medicine and Science in Sports and Exercise, 2008, 40: 275-81.

4. Burke L., Hawley J., Wong S., Jeukendrup A.E.: Carbohydrates for training and competition. J Sports Sci 2011;29 (S1):17-27.

5. Durkalec-Michalski K., Baraniak A., Jeszka J.: Wpływ zbilansowania diety na skład ciała i zdolności wysiłkowe rekreacyjnych biegaczy długodystansowych. [Effect of diet balancing on body composition and physical performance in recreational long-distance runners]. Probl Hig Epidemiol 2015;96(3):662-667 (in Polish). 
6. Hargreaves M., Hawley J.A., Jeukendrup A.: Preexercise carbohydrate and fat ingestion: Effects on metabolism and performance. J Sports Sci 2004;22:31-38.

7. Howarth N.C., Saltzman E., Roberts S.B.: Dietary fiber and weight regulation. Nutr Rev 2001;59:129-139.

8. Kałużny K., Śpica D., Drobik P., Michalska A., Kałużna A., Kochański B., Zukow W.: Evaluation and comparison of nutritional behavior of people practicing professional and amateur sport. J Edu Health Sport 2016;6(2):301- 310 (in Polish).

9. Kasprzak Z., Pilaczyńska-Szcześniak Ł., Czubaszewski $\ell .: \quad$ Strategie żywieniowe w wysiłkach wytrzymałościowych [Nutritional strategies in strength efforts]. Studia i Materiały CEPL w Rogowie 2013;R.15,34(1):104-110 (in Polish).

10. Kozłowska L.: Rola błonnika pokarmowego w utrzymaniu prawidłowej pracy jelit [The role of dietary fiber in maintaining normal bowel function]. Food Health 2010;13:23-27 (in Polish).

11. Nowacka E., Polaszczyk S., Kopeć A., Leszczyńska T., Morawska K., Pysz-Izdebska K.: Częstotliwość spożycia wybranych grup produktów spożywczych przez sportowców trenujących strzelectwo sportowe i kajakarstwo slalomowe [Assessment of selected food frequency intake in shooters and slalom canoeists]. Med Sport 2010;26(2/3):144-150 (in Polish).

12. Ostachowska-Gąsior A., Krzeszowska-Rosiek T., Górska S.: Ocena wiedzy żywieniowej osób o wysokiej aktywności fizycznej uczęszczających do klubów fitness [Evaluation of nutritional knowledge among fit individuals attending fitness clubs]. Probl Hig Epidemiol 2014, 95(4): 969-974 (in Polish).

13. Pałkowska-Goździk E., Stachoń M., Lachowicz K., Lange E.: Rola B-glukanów $\mathrm{z}$ owsa w profilaktyce i terapii chorób układu krążenia oraz cukrzycy typu 2 w: Wybrane problemy dietoprofilaktyki i dietoterapii chorób przewlekłych [The role of oats $\beta$-glucans in the prevention and treatment of cardiovascular diseases and type 2 diabetes in: Selected problems of diteoprevention and dietotherapy of chronic diseases]. Publications PTD, Warszawa, 2016:20-27 (in Polish).

14. Szczepańska E., Spałkowska A.: Zachowania żywieniowe sportowców wyczynowych uprawiających siatkówkę i koszykówkę [Dietary behaviours of volleyball and basketball players]. Rocz Panstw Zakl Hig 2012;63(4):483-489 (in Polish).

15. Szczepańska J., Wądołowska L., Słowińska M.A., Niedźwiedzka E., Biegańska J.: Ocena częstości spożycia wybranych źródeł błonnika pokarmowego oraz ich związku z masa ciała studentów [Frequency of dietary fibre intake and its relationship with the body mass of students]. Bromat Chem Toksykol 2010;(43)3:382-390 (in Polish).

16. Threapleton D.E., Greenwood D.C., Evans C., Cleghorn C.L., Nykjaer C., Woodhead C., Cade J.E., Gale C.P., Burley V.J.: Dietary fiber intake and risk of cardiovascular disease: systematic review and meta-analysis. BMJ 2013;347:f6879.

17. Weickert M.O., Pfeiffer A.F.: Metabolic effects of dietary fiber consumption and prevention of diabetes. $\mathrm{J}$ Nutr 2008;138(3):439-442.

18. Zajac A., Poprzęcki S., Waśkiewicz Z.: Żywienie i suplementacja w sporcie [Nutrition and supplementation in sport]. Wyd. AWF, Katowice, 2007 (in Polish).

Received: 14.03 .2018

Accepted: 18.07 .2018

This article is available in Open Access model and licensed under a Creative Commons Attribution-Non Commercial 3.0.Poland License (CC-BY-NC) available at: http://creativecommons.org/licenses/by-nc/3.0/pl/deed.en 